\title{
ВНЕСОК ГРЕЦЬКИХ УЧЕНИХ-ПЕДАГОГІВ А. ДЕЛМУДОСА, Н. ЕКСАРХОПУЛОСА ТА М. ТРІАНТАФІЛЛІДІСА У РОЗВИТОК УНІВЕРСИТЕТСЬКОЇ ОСВІТИ В КРАЇНІ (20-50-І РОКИ ХХ СТОЛІТТЯ)
}

\author{
Короткова Ю. М. \\ доктор педагогічних наук, дочент, \\ професор кафедри сочіально-гуманітарних дисииплін \\ Донецький юридичний інститут Міністерства внутрішніх справ України \\ пр. Луніна, 89, Маріуполь, Донещька область, Україна \\ orcid.org/0000-0002-6930-9730 \\ y.korotkova1201@ukr.net
}

\begin{abstract}
Ключові слова: Греція, університет, філософський факультет, А. Делмудос, Н. Ексархопулос,

М. Тріантафіллідіс, наукова (спечіальна) підготовка, психолого-педагогічна підготовка, моделі підготовки, мовне питання, диглосія.
\end{abstract}

Статтю присвячено аналізу педагогічної спадщини грецьких ученихпедагогів А. Делмудоса, Н. Ексархопулоса та М. Тріантафіллідіса, а саме досліджено їхній внесок у розвиток університетської освіти в Греції протягом 20-50-х років XX століття. Особливу увагу приділено філософським факультетам Афінського та Салоніцького університетів, на яких працювали зазначені вище вчені. Доведено, що протягом XIX - на початку XX століття у підготовці фахівців на філософських факультетах наукова (спеціальна) підготовка цілковито домінувала над психолого-педагогічною, проте провідні вчені-педагоги А. Делмудос, Н. Ексархопулос, М. Тріантафіллідіс та інші наполягали на обов'язковій психолого-педагогічній підготовці, оскільки значна частина випускників працевлаштовувалася до закладів середньої освіти, не маючи елементарних знань із педагогіки, дидактики і психології. Аналіз праць названих вище учених засвідчив, що останні пропонували паралельну (органічне поєднання наукового та психолого-педагогічного складників: А. Делмудос, М. Тріантафіллідіс) і послідовну (перші три роки наукова підготовка, додатковий четвертий рік - психолого-педагогічна підготовка для тих, хто бажає присвятити себе викладацькій діяльності: Н. Ексархопулос) моделі підготовки фахівців. Доведено, що науковці у своїх працях приділяли серйозну увагу проблемі мети, змісту і структури підготовки майбутніх фахівців, піддаючи систематичному аналізу відповідні навчальні плани і програми. 3'ясовано, що другим питанням, яке постійно хвилювало трьох науковців, було мовне питання. Однак погляди на його вирішення були прямо протилежними. А. Делмудос та М. Тріантафіллідіс були палкими прихильниками народної мови демотики, палко відстоюючи іiі право бути офіційною мовою держави, освіти та науки. Натомість Н. Ексархопулос відстоював позиції штучної архаїзованої мови - катаревуси, демонструючи консервативні погляди на мовне питання.

Беручи до уваги перевірений часом науково-педагогічний досвід зазначених учених, сформульовано деякі рекомендації щодо його творчого застосування в Україні (покращення психолого-педагогічної підготовки фахівців, особливо класичних вишів; якнайскоріше вирішення проблеми українсько-російської диглосії). 


\title{
CONTRIBUTION OF GREEK SCIENTIST-TEACHERS A. DELMUDOS, N. EXARCHOPULOS AND M. TRIANTAFILLIDIS IN THE DEVELOPMENT OF UNIVERSITY EDUCATION IN THE COUNTRY (20-50S OF THE XX CENTURY)
}

\author{
Korotkova Yu. M. \\ Doctor of Pedagogical Sciences, Associate Professor, \\ Professor at the Department of Social Sciences and Humanities \\ Donetsk Law Institute of the Ministry of Internal Affairs of Ukraine \\ Lunina ave., 89, Mariupol, Donetsk region, Ukraine \\ orcid.org/0000-0002-6930-9730 \\ y.korotkova1201@ukr.net
}

Key words: Greece, university, faculty of philosophy, $A$. Delmudos, N. Exarchopoulos, M. Triantafillidis, scientific (special) training, psychological and pedagogical training, training models, language issue, diglossia.

\begin{abstract}
The article is devoted to the analysis of the pedagogical heritage of Greek scientists-teachers A. Delmudos, N. Exarchopoulos and M. Triantafillidis, namely their contribution to the development of university education in Greece in the 20-50s of the XX century. Particular attention is paid to the philosophical faculties of the Universities of Athens and Thessaloniki, where the above mentioned scientists worked. It is proved that during the XIX - early XX century in the training of specialists in philosophical faculties scientific (special) training completely dominated over the psychological and pedagogical ones, but leading scholars such as A. Delmudos, N. Exarchopoulos, M. Triantafillidis and others insisted on psychological and pedagogical training, as a significant part of graduates were employed in secondary schools without even basic knowledge of pedagogy, didactics and psychology. Analysis of the works of the above mentioned scientists showed that the latter offered a parallel (organic combination of scientific and psychological and pedagogical components: A. Delmudos, M. Triandafillidis) and sequential (the first three years of scientific training, the additional fourth year of psychological and pedagogical training for those who wants to dedicate themselves to teaching: N. Exarchopoulos) models of training. It is proved that scientists in their works paid serious attention to the problem of purpose, content and structure of training of future specialists, subjecting to systematic analysis the relevant curricula and programs. It turned out that the second issue that constantly troubled the three scholars was the language issue. However, views on its solution were just the opposite. Thus, A. Delmudos and M. Triantafillidis were ardent supporters of the national language - demotics, fiery defending its right to be the official language of the state, education and science. Instead, N. Exarchopoulos all his life defended the position of artificial archaic language - katarevus, demonstrating conservative views on the language issue.

Taking into account the time-tested scientific and pedagogical experience of these scientists, some recommendations for its creative application in Ukraine have been formulated (improvement of psychological and pedagogical training of specialists, especially classical universities; solving the problem of Ukrainian-Russian diglossia as soon as possible).
\end{abstract}

Постановка проблеми. На межі XX-XXI століть посилився інтерес до вивчення особливостей організації та забезпечення університетської освіти у багатьох країнах світу. Це пояснюється тим, що підготовка фахівців в університеті покликана органічно поєднувати освітню і науководослідну діяльність і тим самим сприяти формуванню високоякісного, конкурентоспроможного науково-технічного, загальноосвітнього, профе- сійного та інтелектуального потенціалів будь-якої держави. Пошук шляхів розв'язання сучасних проблем пов'язаний із вдумливим осмисленням минулого як своєї країни, так і зарубіжних, об'єктивною оцінкою історичних реалій, вивченням історичних коренів соціально-педагогічних ідей, фактів, теорій, концепцій, досвіду педагогів минулих років. 3 огляду на це, корисним може стати дослідження наукової спадщини грецьких 
учених-педагогів Александроса Делмудоса, Ніколаоса Ексархопулоса та Маноліса Тріандафіллідіса, які впродовж життя піклувалися про удосконалення університетської освіти в країні.

Нині вітчизняними і зарубіжними вченими досліджено особливості організації зарубіжних освітніх систем, шляхи їхнього реформування, розвиток і сучасний стан університетської і професійної освіти. Це такі вчені, як Н. Абашкіна (Німеччина), Н. Авшенюк, Н. Яцишин (Велика Британія), Н. Бідюк, Т. Кошманова, О. Романовський (США), А. Василюк (Польща), Н. Воєвутко (Республіка Кіпр), Б. Вульфсон, О. Джуринський, М. Кларін, К. Корсак, П. Кряжев, М. Лещенко, О. Локшина, 3. Малькова, Л. Пуховська (країни Європи), О. Озерська (Японія), А. Сбруєва (країни Свропейського Союзу), В. Семілетко (Норвегія) тощо.

За останнє двадцятиріччя Греція ставала об'єктом наукових пошуків вітчизняних учених-педагогів. Так, дослідники вивчали проблеми організації освіти в Греції (Н. Кисельова, О. Матвієнко), розвиток системи вищої освіти в Греції в умовах іiї приєднання до Болонського процесу (Н. Постригач), питання післядипломної педагогічної освіти в країні (О. Проценко). Проте вивчення вітчизняних науково-педагогічних праць, присвячених системам освіти в зарубіжних країнах, показало, що цілісного дослідження, яке б узагальнило та систематизувало внесок видатних учених-педагогів Греції у становлення і розвиток університетської освіти країни під кутом зору його практичної цінності та доцільності використання окремих ідей і практичних розробок, не проводилося.

3 огляду на це, метою статті є узагальнення та систематизація педагогічно цінного досвіду видатних грецьких науковців, які зробили значний внесок у становлення і розвиток університетської освіти в країні.

Виклад основного матеріалу дослідження. Вивчення науково-педагогічних джерел $[1 ; 2$; 3] засвідчило той факт, що в Греції перший університет було засновано лише в 1837 році. Ним став Грецький Оттонський університет в Афінах. Королівська Постанова «Про тимчасове врегулювання діяльності новоствореного університету в Афінах» від 24 квітня 1837 року стала основним документом, за яким відбувалося функціонування вишу до 1911 року. За цією постановою університет розпочав свою діяльність із чотирма факультетами: філософським, теологічним, медичним та юридичним. Навчання тривало три роки. Навчальний процес забезпечували як іноземні вчені, переважно з Німеччини, так і грецькі науковці, які отримали освіту за кордоном. Повний контроль за діяльністю університету був покладений на Міністерство церковної та державної освіти.
Як зазначають дослідники історії університетської освіти в Греції (С. Бузакіс [4, с. 19-20], А. Вереві [1, с. 24-26]), протягом перших десятиліть іiі рівень був досить низьким, що пояснювалося слабким матеріально-технічним забезпеченням, наданням уваги переважно навчальній роботі без розвитку дослідницьких умінь і навичок студентів, обмеженням форм організації навчального процесу лише лекційними заняттями. Окрім цього, відсутньою була науково обгрунтована теорія укладання навчального плану, не передбачалося розподілу дисциплін на загальні та спеціальні, навчальний рік не поділявся на семестри, відсутніми були й семестрові іспити, вкрай недостатнім було забезпечення навчального процесу відповідними підручниками та посібниками. Також недоліком називалося копіювання іноземних (переважно німецьких) моделей підготовки фахівців без урахування національних особливостей та освітніх традицій.

Значний інтерес для нашого дослідження становить філософський факультет, який готував таких фахівців, як: філологи, філософи, історики-археологи тощо. Як зазначають грецькі науковці (В. Караманолакіс [5], П. Ксохеліс [6, с. 34], П. Папаконстантіну [7, с. 448] та інші), філософський факультет Афінського університету перші роки свого існування був орієнтований виключно на надання наукової (спеціальної) підготовки, без урахування поля майбутньої професії випускників, які здебільшого працевлаштовувалися до закладів середньої освіти - до гімназій. Серед випускних іспитів проводилися лише випробовування $з$ дисциплін спеціальності комісіями, які призначалися Міністерством церковної і державної освіти.

У 1877 році до навчального плану підготовки фахівців було введено дисципліну «Гімназійна педагогіка», яка викладалася дві години на тиждень і включала, окрім теоретичної педагогічної і дидактичної підготовки, практичні вправляння студентів із викладання фахових дисциплін.

На початку другого десятиріччя XX століття відбулися важливі зміни в університетській освіті. Зокрема, в 1911 році Грецький національний університет було розділено на два університети Афінський національний університет та Афінський університет імені I. Каподістрії, названий на честь першого президента Грецької Республіки - I. Каподістрії. Ці два університети мали єдине керівництво в особі одного ректора. На основі Законів 1911 року «Про національний університет» та «Про університет імені І. Каподістрії» до останнього відійшли теологічний, філософський та юридичний факультети, тоді як за національним університетом залишилися фізико-математичний, медичний і фармацевтичний факультети. 
Названими вище Законами було започатковано такі нововведення: подовження терміну навчання в університеті до чотирьох років; обов'язкове введення семінарських занять, яким мало відводитися не менше однієї години на тиждень; обов'язкове видання викладачами навчальної літератури 3 дисципліни. Навчальний план на наступний рік мав затверджуватися на спеціальному зібранні університету у червні кожного поточного року i подаватися на схвалення міністру державної освіти. Тривалість викладання кожної дисципліни не могла перевищувати два роки без спеціального дозволу на це міністра [1, с. 58].

Вивчення передумов підготовки фахівців на філософському факультеті показало, що в першій половині XX століття спеціальна (наукова) підготовка продовжувала переважати над психолого-педагогічною. Якісним змінам у забезпеченні останньої сприяла діяльність Ніколаоса Ексархопулоса (1874-1960). Останній був випускником Афінського університету i продовжив своє навчання в Німеччині. Після повернення на батьківщину Н. Ексархопулос у 1912 році домігся створення кафедри педагогіки. Будучи переконаним у тому, що всі вчителі, незалежно від ланки освітньої галузі, мають отримати належну педагогічну підготовку, теоретичну і практичну, учений домігся створення відповідних закладів з метою педагогічної підготовки викладачів для середньої школи - педагогічного училища середньої освіти

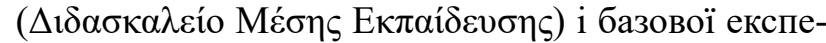

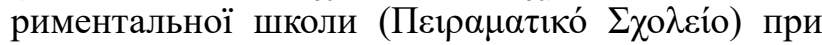
університеті для організації педагогічної практики студентів. Також завдяки його клопотанням 3 1922 року було введено обов'язкове відвідування педагогічних дисциплін студентами теологічного та фізико-математичного факультетів (для студентів філософського факультету таке відвідування було введено раніше). Більше того, в цьому ж році (1922 р.) завдяки активним діям Н. Ексархопулоса було прийнято Закон № 2905 «Про організацію Афінського національного університету імені Каподістрії», статтею 236 якого передбачалося, що випускники університету, які мали намір викладати у школі, повинні були спочатку успішно скласти іспити з педагогічних дисциплін i отримати посвідчення, яке би підтверджувало їхні достатні знання 3 педагогіки. На жаль, цей Закон так і не був утілений у життя.

Слід зазначити, що Афінський університет довгий час (майже сто років) залишався єдиним закладом вищої освіти у країні. Другий університет, який мав у своєму складі філософський факультет, було засновано лише в 1925 році на основі Закону № 3341 від 1925 року «Про створення університету в Салоніках». Ним став Салоніцький університет імені Аристотеля, який розпочав свою діяльність у 1926-1927 навчальному році.

3 початку діяльності філософського факультету Салоніцького університету викладачів турбувало питання про головну мету його роботи. Вивчення матеріалів засідань професорсько-викладацького складу факультету з 1927 по 1931 рік засвідчило наявність двох панівних поглядів на це питання. Прихильники першого, яких була більшість, обстоювали необхідність надання на факультеті виключно наукової (спеціальної) підготовки майбутнім фахівцям; прибічники другої наголошували на потребі забезпечення як наукової, так i професійної (психолого-педагогічної) підготовки студентів філософського факультету.

Так, грецький педагог А. Делмудос (1880-1956), який був професором педагогіки Салоніцького університету в періоди 1929-1934 та 1936-1938 рр., наполягав на необхідності надання наукової і професійної (педагогічної) підготовки, які є неподільними [8, с. 398-402; 3, с. 148].

Так само й інший учений-педагог М. Тріантафіллідіс (1883-1959), який викладав у Салоніцькому університеті до 1934 року, зазначав, що «університетська освіта має орієнтуватися на потреби середньої освіти, бо певного дня випускник філософського факультету прийде працювати до школи, і це необхідно враховувати під час укладання навчального плану» [8, с. 398-402].

Слід зазначити, що до 1930 року навчальний план підготовки фахівців не був досить збалансованим і науково обгрунтованим, що викликало невдоволення серед прогресивно налаштованих викладачів філософського факультету. Так, А. Делмудос у 1930 році наполягав на необхідності подолання енциклопедизму, який вважав головним недоліком підготовки майбутніх фахівців, а також на збільшенні частки навчального часу на підготовку за вибраною спеціалізацією. Учений нарікав, що навчання за спеціалізацією відбувається хаотично, без науково обгрунтованого відбору відповідних навчальних дисциплін та їх змісту. Задля запобігання енциклопедизму А. Делмудос пропонував увести «скелет дисциплін» (обов'язкових, єдиних для всіх студентів) та дисциплін вільного вибору згідно з науковими і професійними інтересами майбутніх фахівців [7, c. 338-342; 3, c. 151-152].

Суттєвому покращенню університетської освіти в Греції сприяли зміни в іiі організації і забезпеченні. Так, на підставі Закону № 5343 від 1932 року «Про Афінський університет» два університети - Афінський національний університет та Афінський університет імені І. Каподістрії знову було об'єднано в один заклад, який став називатися Афінським національним університетом імені І. Каподістрії. Така назва збереглась і 
до наших днів. Окрім цього, університет отримав широку автономію. Відбулися суттєві зміни і в організації освітнього процесу завдяки діям прогресивно налаштованих учених-педагогів. Так, у кожному відділенні почали створюватися бібліотеки та нові лабораторії, розширився спектр семінарсько-практичних занять, активізувалася науково-пошукова та видавнича діяльність професорсько-викладацького складу, на студентів накладався обов'язок володіння однією іноземною мовою для отримання можливості відстежувати розвиток своєї наукової галузі у світовій науці.

Варто зазначити, що в 1938 році до влади прийшов новий уряд, відомий в історичний науці як Диктатура полковника Метаксаса, який позбавив університети вагомої частини автономії (Закон № 1430 від 1938 року). 40-і роки також були складними для Греції через події, пов'язані з Другою світовою війною та громадянською війною в країні. У цей час не вийшло жодного законодавчого документа, який би сприяв суттєвому покращенню університетської освіти.

Проте вчені Греції не полишали пошуку шляхів покращення університетської освіти в країні. Так, Н. Ексархопулос у своїх працях продовжував наголошувати на необхідності надання якісної психолого-педагогічної підготовки тим студентам, які мали намір присвятити себе викладацькій діяльності [9]. Зміст теоретичної психолого-педагогічної підготовки, на думку Н. Ексархопулоса, повинен передбачати такі теми, як: етика; психологія дитини; анатомія, фізіологія, здоров'я дитини; історія педагогіки. Методична підготовка мала охоплювати питання добору і розподілу навчального матеріалу; застосування методів, способів, засобів викладання мови; організації контролю; планування навчального процесу з мови [9].

Ще одним питанням, яке хвилювало трьох учених, було мовне питання. Тут варто пояснити, що в Греції з початку XIX століття існувало два різновиди (стилі) грецької мови: катаревуса і демотика. Катаревуса ( $\uparrow \alpha \theta \alpha \rho \varepsilon v ́ o v \sigma \alpha$ в перекладі 3 грець-

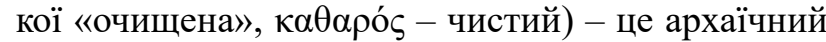
книжний стиль, штучне наближення новогрецької мови до давньогрецької. Катаревусою на належному рівні володіли лише вищі верстви насе-

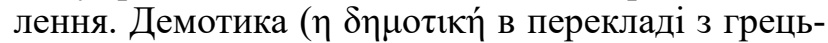
кої «народна») - відображення розмовної мови широких народних мас. Між прихильниками катаревуси (так званими «архаїстами») та демотики («демотикістами») протягом усього XIX століття велася запекла боротьба стосовно того, якій 3 цих двох мов бути державною мовою Греції, мовою освіти та науки. Кожний уряд як державну вводив то катаревусу, то демотику, від чого страждала якість грецької освіти на всіх їі рівнях.
Так, А. Делмудос ще на початку ХХ століття писав, що випускники початкової школи не оволодівали на належному рівні жодною мовою (ані катарувесою, ані демотикою), і застерігав, що «пізніше це буде виливатися в їхню духовну анархію» [10, с. 261]. Учений говорив: «Коли нація означає всіх людей, яких вона об'єднує, а не лише певну групу осіб, коли грецька нація $\epsilon$ справді жива, тоді катаревуса не може бути мовою національною, а іiі повернення до початкової школи перешкоджає освіті народу, шкодить їй $[10$, с. 315$] »$. Так само М. Тріантафіллідіс у 1909 році після відвідування грецьких шкіл писав, що навіть не очікував побачити такі глибокі рани в освіті, які спричинила офіційна мова (катаревуса). За його словами, десятки тисяч дітей страждали щороку, щодня, щогодини, і все це без позитивного результату, бо офіційна мова була мовою мертвою [12, с. 58-59].

Зазначимо, що більшість викладачів університетів (особливо Афінського) відстоювали виключно катаревусу. Одним із них був Н. Ексархопулос, який до кінця життя наполягав на необхідності вивчення грецькими учнями і студентами виключно катаревуси. Так, у своїй статті «Викладання рідної мови та діяльність нової комісії з питань освіти» (1958р.) учений наполягав, що вивчати слід лише офіційну літературну мову - катаревусу. Звідси завданням учителя-філолога вчений називав сприяння мовному розвитку учнів і студентів та забезпечення безболісного переходу від діалектної мови до «офіційної правильної мови освічених людей, в якій проявляється дух нації» $[13$, с. 57-58].

Одним із палких противників цього був М. Тріантафіллідіс, який уперше в історії грецької університетської освіти звернувся до студентів-першокурсників народною мовою (демотикою), домігся дозволу абітурієнтам складати письмовий іспит, використовуючи за бажанням або демотику, або катаревусу, вважав важливим донести до студентів думку про те, що демотика - це природна мова, яка має свої закони і правила, яка здатна повністю замінити штучну катаревусу без нанесення будь-якої шкоди духовному розвитку грецької нації, як на цьому наполягали представники катаревуси. Цій меті були підпорядковані дисципліни, які він викладав на філософському факультеті [3, с. 178-179]. Більше того, М. Тріантафіллідіс у 1941 році уклав першу граматику новогрецької мови (демотики), за якою грецькі учні й студенти навчаються і донині.

На жаль, мовне питання ще довгий час не було вирішено, кожний новий уряд уводив в освіту то катаревусу, то демотику, від чого страждала якість грецької системи освіти загалом. I лише у 1975 році була прийнята нова Конституція Греції, 
якою демотика визнавалася єдиною офіційною мовою держави і почала використовуватися на всіх рівнях державного управління й освіти. Так була остаточно вирішено проблема диглосії, від якої страждала якість грецької освіти майже протягом двох століть.

Висновки i перспективи подальших розробок у цьому напрямі. Науково-педагогічні погляди трьох учених (А. Делмудоса, Н. Ексархопулоса та М. Тріантафіллідіса) об'єднувалися навколо таких питань, як: мета, зміст і структура підготовки фахівців філософського факультету, мовна освіта та мовне питання у Греції. Стосовно першого питання всі три науковці наполягали на необхідності надання студентам факультету обов'язкової психолого-педагогічної підготовки, хоча й пропонували різні моделі іiі забезпечення (А. Делмудос та М. Тріантафіллідіс - паралельну, Н. Ексархопулос - послідовну). Щодо другого питання, то тут погляди науковців були прямо протилежними: якщо А. Делмудос та М. Тріантафіллідіс були палкими прихильниками народної мови - демотики, то Н. Ексархопулос усе життя відстоював позиції штучної катаревуси. Проте, як відомо, врешті-решт у країні з 1975 року офіційною мовою держави, науки й освіти визнано саме демотику.

Беручи до уваги перевірений часом науково-педагогічний досвід зазначених учених, можемо сформулювати деякі рекомендації щодо його творчого застосування в Україні. По-перше, не варто недооцінювати значення психолого-педагогічної підготовки фахівців, які за своїм фахом можуть працевлаштуватися до закладів освіти. По-друге, Україна має якнайскоріше вирішити проблему українсько-російської диглосії шляхом безкомпромісного розповсюдження української мови на теренах держави у всіх сферах суспільного життя.

Проведене дослідження не вичерпує всіх аспектів проблеми, яка вивчається. Подальшого вивчення потребує історико-педагогічний досвід організації і забезпечення університетської освіти інших розвинених країн світу 3 метою його творчого застосування в освітньому процесі вітчизняних закладів вищої освіти.

\section{ЛІТЕРАТУРА}

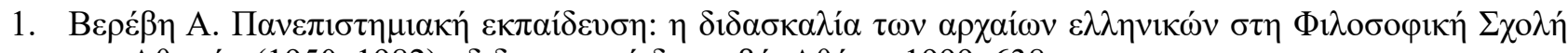

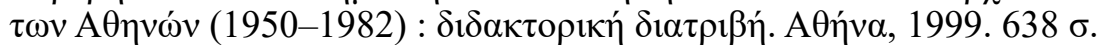

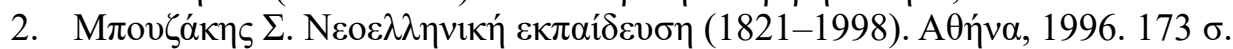

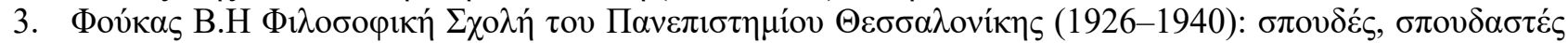

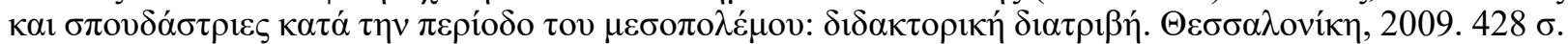

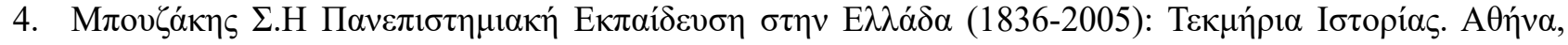
2005. T. B: (1926-2005). $775 \sigma$.

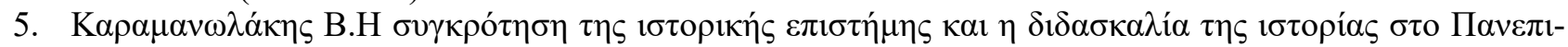

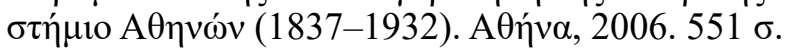

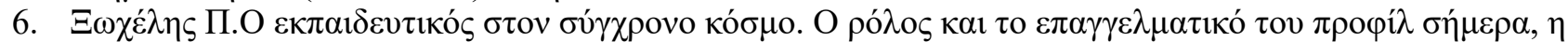

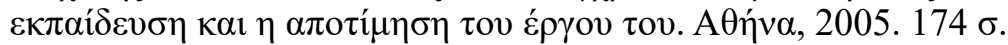

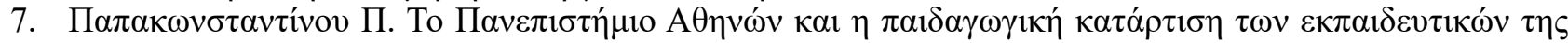

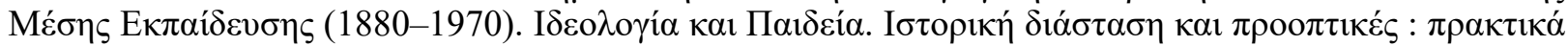

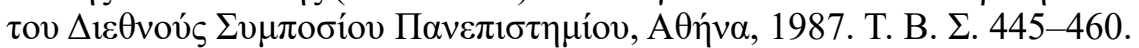

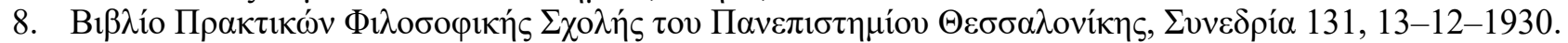

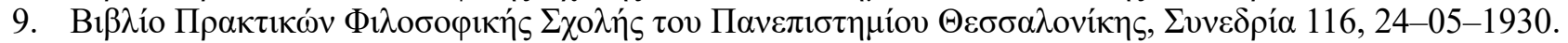

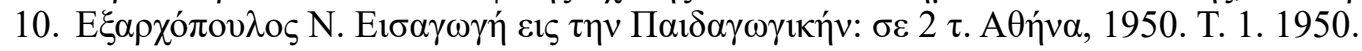

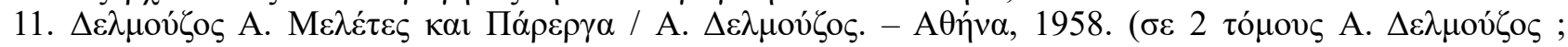
$\left.\tau o ́ \mu \circ \mathrm{B}^{\prime}\right)$.

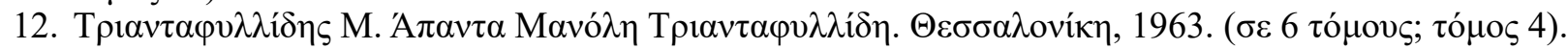

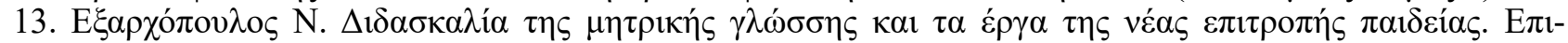

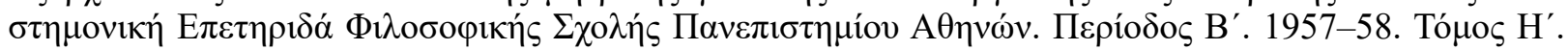
इ. 189-217.

\section{REFERENCES}

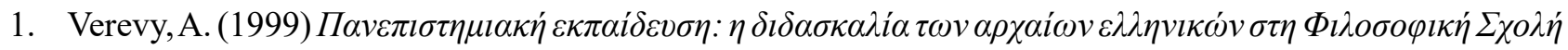
$\tau \omega v A \theta \eta v \omega ́ v$ (1950-1982) [University Education: Teaching Ancient Greek in the School of Philosophy of

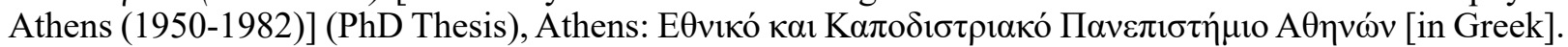

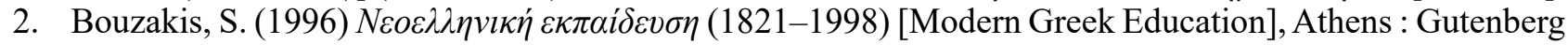
[in Greek].

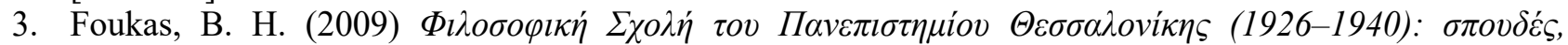

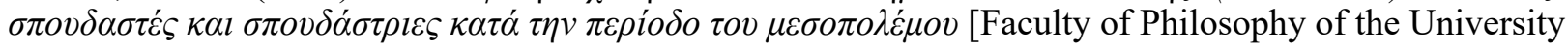


of Thessaloniki (1926-1940): studies and students during the interwar period] (PhD Thesis), Thessaloniki:

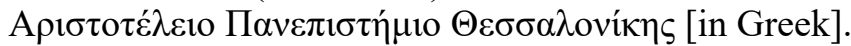

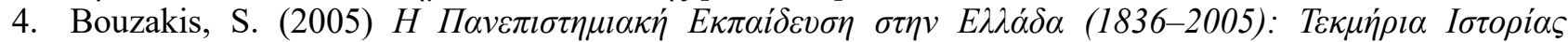
[University Education in Greece (1836-2005): History Items], in 2 vols., Vol. B. (1926-2005), Athens: Gutenberg [in Greek].

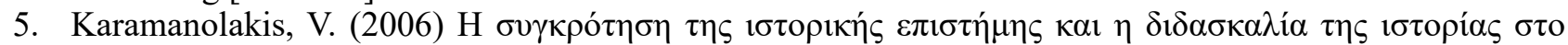

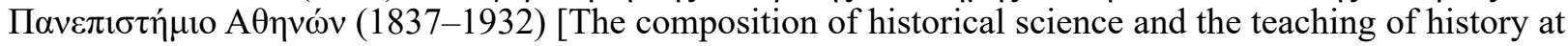

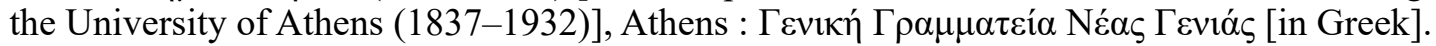

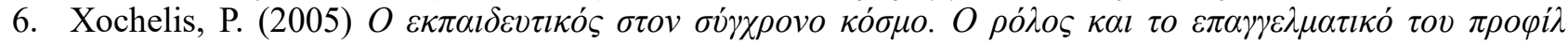

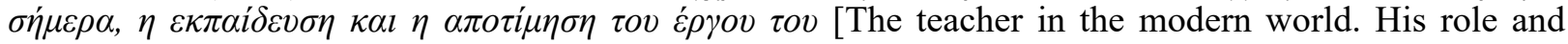
professional profile today, the education and the evaluation of his work], Athens : Gutenberg [in Greek].

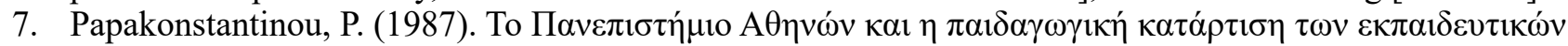

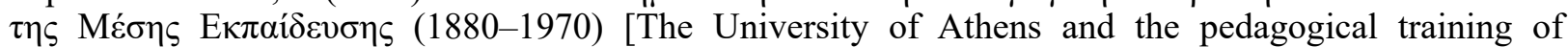

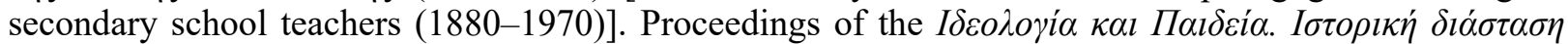

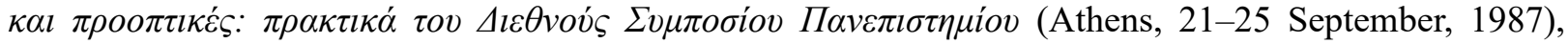

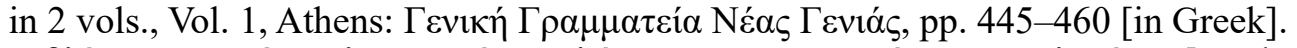

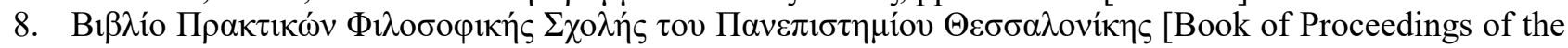
Faculty of Philosophy of the University of Thessaloniki] (1930). Session 131, 13-12-1930, Thessaloniki :

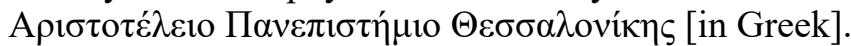

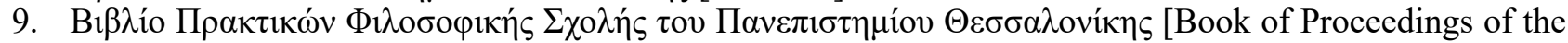
Faculty of Philosophy of the University of Thessaloniki] (1930). Session 116, 24-05-1930, Thessaloniki :

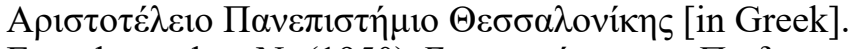

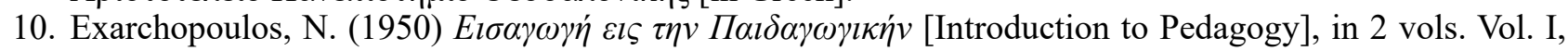
Athens : $\varepsilon \kappa \delta . \mathrm{E} \Lambda \mathrm{IK} \Omega \mathrm{N}$ [in Greek].

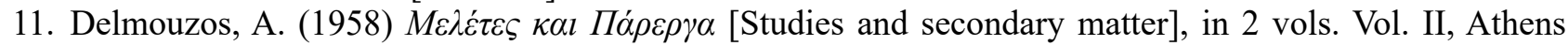
[in Greek].

12. Triantaphyllidis, M. (1963) Á

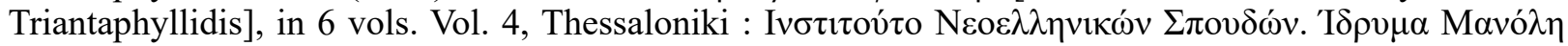

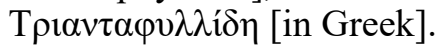

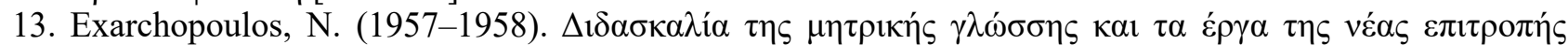

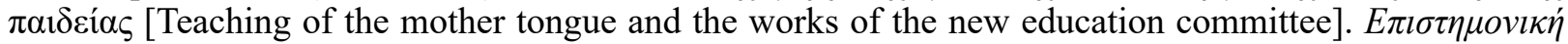

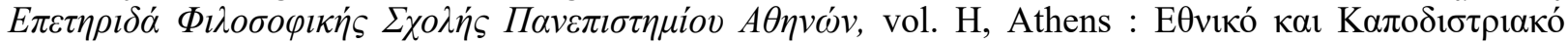

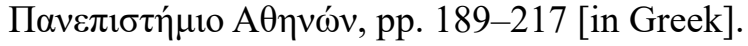

